\title{
Type B insulin resistance syndrome with Scleroderma successfully treated with multiple immune suppressants after eradication of Helicobacter pylori infection: a case report
}

\author{
Guo-Qing Yang ${ }^{\dagger}$, Yi-Jun $\mathrm{Li}^{\dagger}$, Jing-Tao Dou, Bao-An Wang, Ju-Ming Lu and Yi-Ming Mu*
}

\begin{abstract}
Background: Type B insulin resistance is a rare autoimmune disease characterized by the presence of autoantibodies against the insulin receptor. Helicobacter pylori (H pylori) infection may play a causative role in the autoimmune diseases.

Case presentation: Here, we present a rare case of a 48-year old female patient, who had type B insulin resistance with systemic scleroderma and was successfully treated with multiple immune suppressants after eradication of Helicobacter pylori infection.

Conclusion: The present case suggests $\mathrm{H}$ pylori infection-related pathological mechanism may contribute to type $\mathrm{B}$ insulin resistance syndrome and autoimmune disorders. Treatment toward $\mathrm{H}$ pylori may be helpful to relieve syndrome of type B insulin resistance for $\mathrm{H}$ pylori positive patients.
\end{abstract}

Keywords: Type B insulin resistance, Systemic scleroderma, Helicobacter pylori infection

\section{Background}

Type B insulin resistance is a rare autoimmune disease characterized by the presence of anti-insulin receptor antibodies, which impair the binding of insulin to its receptor and cause severe insulin resistance (IR) $[1,2]$. The majority of patients present with severe hyperglycemia and extreme insulin resistance because of the insulin receptorantagonizing action of the autoantibodies, but some patients may present with hypoglycemia due to agonist activity of anti-insulin receptor antibodies [3]. Type B insulin resistance often occurs to patients with autoimmune diseases, such as systemic sclerosis, systemic lupus erythematosus and Sjogren's syndrome [1]. The exact etiology of these autoimmune diseases remains unclear, but it has long been suggested that exposure to certain

\footnotetext{
* Correspondence: muyiming@301 hospital.com.cn

${ }^{\dagger}$ Equal contributors

Department of Endocrinology, Chinese PLA General Hospital, No. 28th Fu

Xing Road, Beijing 100853, China
}

(c) 2016 Yang et al. Open Access This article is distributed under the terms of the Creative Commons Attribution 4.0 International License (http://creativecommons.org/licenses/by/4.0/) which permits unrestricted use, distribution, and reproduction in any medium, provided you give appropriate credit to the original author(s) and the source, provide a link to the Creative Commons license, and indicate if changes were made. The Creative Commons Public Domain Dedication waiver (http://creativecommons.org/publicdomain/zero/1.0/) applies to the data made available in this article, unless otherwise stated. environmental agents, such as viral and bacterial infection, in genetically susceptible individuals may be the catalyst for the initiation of autoimmune processes $[4,5]$. Helicobacter pylori ( $H$ pylori) infection can affect the host immune response by a number of means and may play a causative role in the autoimmune diseases [4]. Thus, therapy focusing on the elimination of $H$ pylori may be helpful to induce the remission of these autoimmune diseases. In this report, we describe the clinical course of a female patient with type B insulin resistance and scleroderma, who was successfully treated with multiple immunosuppressants after eradication of $H$ pylori infection.

\section{Case presentation}

A 48-year-old Chinese woman presented with polydipsia and polyuria in January 2011. Her fasting blood glucose (FBG) and postprandial blood glucose (PBG) were $5.41 \mathrm{mmol} / \mathrm{L}$ and $25.79 \mathrm{mmol} / \mathrm{L}$ respectively and $\mathrm{HbA} 1 \mathrm{c}$ was $11.9 \%$ (normal range $4.1-6.5 \%$ ). On physical 
examination, her weight was $43 \mathrm{~kg}$, height $149 \mathrm{~cm}$, BMI $19.4 \mathrm{~kg} / \mathrm{m}^{2}$. She had no family history of diabetes. The patient was initially diagnosed as type 2 diabetes followed treatment with metformin, pioglitazone and acarbose. The treatment did not relieve her symptoms and her blood glucose could not be controlled.

The patient also complained of Raynaud's phenomenon and morning stiffness in the joints of her both hands in the past 2 years. Skin hardening was observed in her hands, and her fingers were swollen and hard to flex. The first admission laboratory tests were shown in Table 1 . Her liver function and kidney function were normal. Erythrocyte sedimentation rate (ESR), C-reactive protein
(CRP) and rheumatoid factor were in normal range. $\gamma$ globulin was $30.4 \%(11.1-18.8 \%$. Serological data showed increased levels of IgG and Ig E, decreased levels of serum C3, and positive antinuclear antibodies (1:1000). Antiglutamic acid decarboxylase (GAD) and anti-insulin antibodies were negative, but anti-insulin receptor antibodies were detected (ELISA, Abcam, China) (strong positive). The response to a 75-g oral glucose tolerance test (75 gOGTT) was clearly abnormal (Table 2) with marked hyperglycemia and hyperinsulinemia. Leptin and adiponectin levels were $16 \mathrm{pg} / \mathrm{mL}(102 \pm 89 \mathrm{pg} / \mathrm{mL})$ and $35.8 \mathrm{ng} / \mathrm{mL}(5.6 \pm 3.2 \mathrm{ng} / \mathrm{mL})$ respectively. Microcirculation nailfold test showed the decreased number of

Table 1 Biochemical and Serological Evaluation

\begin{tabular}{|c|c|c|c|c|}
\hline Item & 1st admission & 2nd admission & 3rd admission & Reference range (Unit) \\
\hline Platelets & 110 & 154 & 130 & $10^{9} / \mathrm{L}$ \\
\hline Creatinine & 36.3 & 33.8 & 39.9 & 44-106 $\mu \mathrm{mol} / \mathrm{l}$ \\
\hline Total protein & 67.0 & 65.7 & 66.2 & $55-80 \mathrm{~g} / \mathrm{L}$ \\
\hline Albumin & 30.7 & 36.4 & 39 & $35-50 \mathrm{~g} / \mathrm{L}$ \\
\hline ALT & 23.4 & 29.5 & 15.5 & 0-35 U/L \\
\hline AST & 19.1 & 19.7 & 19.6 & 0-35 U/L \\
\hline Cholesterol & 2.88 & 2.88 & 2.79 & $3.1-5.7 \mathrm{mmol} / \mathrm{L}$ \\
\hline Triglyceride & 0.56 & 0.56 & 0.48 & $0.4-1.7 \mathrm{mmol} / \mathrm{L}$ \\
\hline LDL-C & 0.88 & 1.79 & 1.05 & mmol/L \\
\hline HDL-C & 1.46 & 1.02 & 1.59 & $\mathrm{mmol} / \mathrm{L}$ \\
\hline IGF-1 & 25 & - & - & 116-358 ng \\
\hline$\Pi_{4}$ & 95.6 & 69.6 & 66.0 & $55.3-160.88 \mathrm{nmol} / \mathrm{L}$ \\
\hline $\mathrm{FT}_{4}$ & 9.63 & 10.4 & 10.66 & 10.42-24.62 pmol/L \\
\hline$\Pi_{3}$ & 0.79 & 0.68 & 1.03 & $1.01-2.95 \mathrm{nmol} / \mathrm{L}$ \\
\hline $\mathrm{FT}_{3}$ & 2.46 & 2.19 & 3.33 & 2.76-6.3 pmol/L \\
\hline TSH & 0.80 & 0.55 & 0.66 & $0.35-5.5 \mathrm{mU} / \mathrm{L}$ \\
\hline $\operatorname{TgAb}$ & 95.2 & 32.8 & 10.5 & $<60 \mathrm{IU} / \mathrm{L}$ \\
\hline TPOAb & 105.2 & 101.1 & 21.8 & $<60 \mathrm{IU} / \mathrm{L}$ \\
\hline UFC & 198.7 & - & - & $153.2-789.4 \mathrm{mmol} / 24 \mathrm{~h}$ \\
\hline FSH & 3.91 & 2.02 & & $1.5-33.4 \mathrm{IU} / \mathrm{L}$ \\
\hline LH & 0.55 & 0.15 & & $0.5-76.3 \mathrm{mlU} / \mathrm{ml}$ \\
\hline Testosterone & 1.22 & 1.07 & & $0.5-2.6 \mathrm{nmol} / \mathrm{L}$ \\
\hline ICA & negative & - & - & Negative \\
\hline IAA & negative & - & - & Negative \\
\hline GAD & negative & - & - & Negative \\
\hline INSR antibody & Positive $(+++)$ & & Negative & Negative \\
\hline DOB(Urea breath test) & - & 19.7 & 0 & $\leq 4.0$ \\
\hline $\lg E$ & 1630 & 887 & 523 & 0-100 IU/ml \\
\hline $\lg G$ & 1960 & 1720 & 1650 & 700-1600 mg/ml \\
\hline C3 & 29.8 & 56.5 & 73.3 & $90-180$ mg/dl \\
\hline C4 & 12.9 & 13.4 & 14.9 & $10-40 \mathrm{mg} / \mathrm{dl}$ \\
\hline ANA & 1:1000 & $>1: 1000$ & $1: 640$ & Negative \\
\hline
\end{tabular}


Table 2 Pre- and post-treatment serum levels of blood glucose, insulin and C-peptide after $75 \mathrm{~g}$ oral glucose tolerance test

\begin{tabular}{|c|c|c|c|c|c|c|}
\hline & \multicolumn{2}{|l|}{$0 \mathrm{~min}$} & \multicolumn{2}{|l|}{$60 \mathrm{~min}$} & \multicolumn{2}{|l|}{$120 \mathrm{~min}$} \\
\hline & Pre-treatment & Post treatment & Pre-treatment & Post treatment & Pre-treatment & Post treatment \\
\hline Blood glucose (mmol/L) & 4.47 & 6.45 & 13.56 & 7.46 & 17.51 & 8.56 \\
\hline Seruminsulin (mU/L) & 118.7 & 10.57 & 192.1 & 145.5 & 452.7 & 235 \\
\hline C-peptide(ng/mL) & 1.33 & 0.87 & 2.65 & 1.79 & 6.78 & 3.69 \\
\hline
\end{tabular}

microvessels and irregularly enlarged loops and capillary hemorrhage in her both hands. According to the above manifestations, the patient was diagnosed with type B insulin resistance with Scleroderma.

Anti-hyperglycemic agents were initiated, but there was minimal response to multiple oral medications given at high doses, including glymepiride $6 \mathrm{mg} /$ day, metformin $2.0 \mathrm{~g} /$ day, and pioglitazone $30 \mathrm{mg} /$ day. Insulin therapy was added, but her blood glucose was higher than $15 \mathrm{mmol} / \mathrm{L}$ in the daytime despite that doses were up to 18,000 units/day with continuous insulin (including human regular insulin and rapid-acting insulin) infusion. Methylprednisolone (600 mg/day) was infused for 3 days, followed by prednisone $(30 \mathrm{mg} / \mathrm{d})$ and azathioprine $(100 \mathrm{mg} / \mathrm{d})$. After 4 weeks, prednisone dose was gradually reduced by $5 \mathrm{mg}$ weekly until a 5 -mg maintenance dose was reached, followed by an additional 8 weeks in maintenance dose. These drugs were withdrawn after 16 weeks. Glymepiride, metformin, and pioglitazone were continued, and subcutaneous insulin injections were prescribed (regular human insulin $20 \mathrm{U}$ before every meals, and NPH $10 \mathrm{U}$ at bedtime).

In her second hospitalization in May 2012, her HbA1c was elevated at $15.3 \%$. She complained stomachache, and $H$ pylori infection was diagnosed based on the carbon-13 urea breath test. She was treated with quadruple eradication therapy (amoxicillin, esomeprazole, clarithromycin and bismuth potassium citrate) for 2 weeks. Her immunosuppressive therapy switched to tripterygium $20 \mathrm{mg}$ tid,azathioprine $(100 \mathrm{mg} / \mathrm{d})$ and cyclophosphamide $60 \mathrm{mg} / \mathrm{d}$ (Fig. 1). Thereafter, the skin lesion of hands and Raynaud's phenomenon improved gradually. Meantime, her glycemic control began to improve. HbA1c was decreased to 10.6 and $8.7 \%$ on August and
December 2012 respectively, without hypoglycemic episodes. Carbon-13 urea breath test was repeated in Dec 2012 and the result was negative. In the beginning of 2013, she experienced hypoglycemic symptoms, with blood glucose levels between 3.4 to $4.6 \mathrm{mmol} / \mathrm{L}$.

In March 2013, on her third admission, all biochemical and serological parameters were repeated (Table 1). Her HbA1c levels were normal at $5.9 \%$ though 75-g OGTT (Table 2) showed that the hyperglycemia and hyperinsulinemia were improved significantly. Repeated insulin receptor antibody testing revealed that her insulin receptor antibody had become negative. Serological data showed that Ig G, Ig E and complement levels were near normal, and titer of antinuclear antibodies was decreased. Urea breath test of $H$ pylori remained negative. At further follow-up, the patient remained euglycemic and no any anti-hyperglycemia therapy was prescribed.

\section{Conclusions}

The case presents a patient who had extremely high endogenous insulin secretion but remained hyperglycemic (glucose levels $16.7-27.8 \mathrm{mmol} / \mathrm{l}$ ) even on intravenous insulin (either regular or aspart) doses as high as 18,000 $\mathrm{U} /$ day, thus she had severe insulin resistance. There are two syndromes associated with severe insulin resistance, type A and type B. Type A insulin resistance syndrome is a genetic disease resulting from mutations in the insulin receptor gene. Type B insulin resistance is caused by autoantibody directed against the insulin receptor. The diagnosis of type B insulin resistance syndrome is based on the presence of hyperglycemia (sometimes hypoglycemia paradoxically), hyperinsulinemia and positive insulin receptor antibodies. Our patient presented with severe hyperglycemia and hyperinsulinemia, and

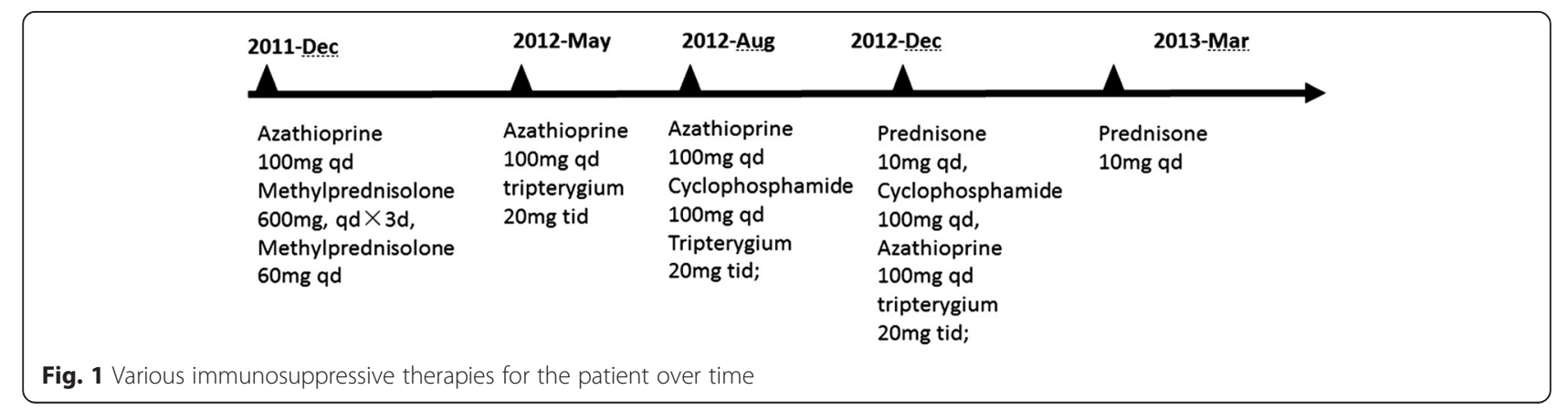


her other clinical features were also consistent with type $B$ insulin resistance described by Arioglu E et al. [1]. Besides, the diagnosis of type $B$ insulin resistance was confirmed by the presence of insulin receptor antibody.

Type B insulin resistance syndrome is frequently associated with other autoimmune diseases. Based on literature review, there have been only one case report of type $B$ insulin resistance associated with scleroderma [6]. Scleroderma (Systemic sclerosis) is a heterogeneous disease typically presented with 3 hallmarks: small vessel vasculopathy, production of autoantibodies, and fibroblast dysfunction leading to increased deposition of extracellular matrix [7]. Typical scleroderma is classically defined as symmetrical skin thickening, with Raynaud's phenomenon presented in about $90 \%$ of cases, nail-fold capillary changes, and antinuclear antibodies [7]. Systemic involvement may or may not be present. Additional symptoms of scleroderma typically present with two years' Raynaud's phenomenon. In our case, the patient had typical skin changes, nail-fold capillary abnormalities, antinuclear antibodies detected by biochemical and serologic tests, elevated Ig E and Ig G, and low level of complement (C3). These manifestos collectively led to the diagnosis of scleroderma according to ACR/EULAR (American College of Rheumatology/European League Against Rheumatism) classification criteria of systemic sclerosis [8]. So it was confirmed that type B insulin resistance and scleroderma occurred concomitantly. However, the mechanisms for the development of antiinsulin-receptor antibodies in this autoimmune disorder remain unknown.

$H$ pylori may play a pathogenetic role in the development of these two conditions. $H$ pylori is a spiralshaped, flagellated, Gram-negative bacterium, which is directly implicated in several gastrointestinal diseases such as dyspepsia, acute and chronic gastritis, and peptic ulceration [9]. H pylori is associated with some extragastric diseases, including autoimmune diseases and endocrine diseases. Some reports suggested that HOMA -IR in $H$ pylori positive patients was higher than that in $H$ pylori negative ones [10]. But there is only one case available, which suggests $H$ pylori infection could be underlying pathological mechanism of type $B$ insulin resistance syndrome. Meanwhile, some studies suggest a possible role of $H$ pylori in the development of scleroderma [11-15]. In a much larger cohort of 124 Japanese patents with systemic sclerosis, prevalence of anti- $H$ pylori antibodies was reported as $55.6 \%$-much higher than that in the healthy controls [16]. Regarding to the mechanism, It is hypothesized that $H$ pylori induces immune dysregulation and aggravating the course of scleroderma [17].

The treatment of type B insulin resistance should focus on the improvement of insulin resistance, glucose abnormalities, and the immune disorders. The antihyperglycemia therapy includes insulin therapy and oral hypoglycemic agents. The dose of insulin needed to control hyperglycemia is typically high. Insulin sensitizers are usually prescribed in this condition, but the efficacy of these drugs has not been clearly studied. Nevertheless, metformin has been reported to improve insulin resistance and reduce the dose of exogenous insulin needed to control hyperglycemia in patient with anti-insulin receptor antibodies [18]. Various immune-modulating therapies such as corticosteroids, plasmapheresis, cyclophosphamide, cyclosporine, azathioprine, mycophenolate mofetil, and rituximab have been tried. Corticosteroids are the most commonly used medicine to control the autoimmune process. In addition, cyclophosphamide or plasmapheresis has been successfully used in type B insulin resistance syndrome. The patient had no response to the combined therapy including insulin and several oral hypoglycemic agents. Initially, a combination therapy including steroids, azathioprine and tripterygium failed to reduce the disease activity in this case. However, the patient's blood glucose improved gradually and skin lesions relieved after therapies aiming at $H$ pylori infection on the basis of combined immunotherapy. Until now, it is unclear whether $H$ pylori eradication improves skin manifestations of scleroderma and insulin resistance in patients. At least, in primary Raynaud's phenomenon, eradication of $H$ pylori infection was reported to be associated with complete remission in some cases and relieved symptoms in most of the treated patients [19]. H pylori eradication also ameliorated type B insulin resistance syndrome [20].

The present case suggests $H$ pylori infection-related pathological mechanism may contribute to type B insulin resistance syndrome and autoimmune disorders. In cases of type B insulin resistance syndrome, testing for $H$ pylori infection may be worthwhile and eradication of $H$ pylori should be considered as a therapeutic option, which may relieve the syndrome of type B insulin resistance.

\section{Declarations \\ Ethics and consent to participate statement}

This study was approved by the Ethics Committee of Chinese People's Liberation Army General Hospital, China. Written informed consent was obtained from the patient for publication of this Case report. A copy of the written consent is available for review by the Editor of this journal.

\section{Consent to publish statements}

Consent for publication of the data was obtained from the patient. 


\section{Availability of data and materials statement} All the data supporting the findings in this study are presented in this article.

\section{Abbreviations}

H pylori: Helicobacter pylori; IR: insulin resistance; FBG: fasting blood glucose; PBG: postprandial blood glucose; ESR: Erythrocyte sedimentation rate; CRP: Creactive protein; GAD: glutamic acid decarboxylase.

\section{Competing interest}

The authors declare that they have no competing interests.

\section{Authors' contributions}

GQY, YJL, and YMM designed the study, collected the data and wrote the manuscript. JTD, BAW, and JML collected the data. All authors read and approved the final manuscript.

Received: 12 October 2015 Accepted: 14 April 2016

Published online: 03 May 2016

\section{References}

1. Arioglu E, Andewelt A, Diabo C, Bell M, Taylor SI, Gorden P. Clinical course of the syndrome of autoantibodies to the insulin receptor (type B insulin resistance): a 28-year perspective. Medicine (Baltimore). 2002;81:87-100.

2. Di Pentima MC, Chan S, Hossain J. Benefits of a pediatric antimicrobial stewardship program at a children's hospital. Pediatrics. 2011;128:1062-70.

3. Flier JS. Lilly Lecture: syndromes of insulin resistance. From patient to gene and back again. Diabetes. 1992;41:1207-19.

4. Smyk DS, Koutsoumpas AL, Mytilinaiou MG, Rigopoulou El, Sakkas LI, Bogdanos DP. Helicobacter pylori and autoimmune disease: cause or bystander. World J Gastroenterol. 2014;20:613-29.

5. Vieira SM, Pagovich OE, Kriegel MA. Diet, microbiota and autoimmune diseases. Lupus. 2014;23:518-26.

6. Bloise W, Wajchenberg BL, Moncada W, Marcus-Samuels B, Taylor SI. Atypical antiinsulin receptor antibodies in a patient with type B insulin resistance and scleroderma. J Clin Endocrinol Metab. 1989;68:227-31.

7. Fett N. Scleroderma: nomenclature, etiology, pathogenesis, prognosis, and treatments: facts and controversies. Clin Dermatol. 2013;31:432-7.

8. van den Hoogen F, Khanna D, Fransen J, Johnson SR, Baron M, Tyndall A, et al. 2013 classification criteria for systemic sclerosis: an American College of Rheumatology/European League against Rheumatism collaborative initiative. Arthritis Rheum. 2013;65:2737-47.

9. Storr M. Helicobacter pylori - Update 2013. Med Monatsschr Pharm. 2013:36:172-6. quiz 7-8

10. Polyzos SA, Kountouras J, Zavos C, Deretzi G. The association between Helicobacter pylori infection and insulin resistance: a systematic review. Helicobacter. 2011;16:79-88.

11. Radic M, Martinovic Kaliterna D, Bonacin D, Morovic Vergles J, Radic J. Correlation between Helicobacter pylori infection and systemic sclerosis activity. Rheumatology (Oxford). 2010;49:1784-5.

12. Radic M, Kaliterna DM, Radic J. Helicobacter pylori infection and systemic sclerosis-is there a link? Joint Bone Spine. 2011;78:337-40

13. Radic M, Kaliterna DM, Bonacin D, Vergles JM, Radic J, Fabijanic D, et al. Is Helicobacter pylori infection a risk factor for disease severity in systemic sclerosis? Rheumatol Int. 2013:33:2943-8.

14. Radic M, Martinovic Kaliterna D, Radic J. Infectious disease as aetiological factor in the pathogenesis of systemic sclerosis. Neth J Med. 2010;68:348-53.

15. Reinauer S, Goerz G, Ruzicka T, Susanto F, Humfeld S, Reinauer H. Helicobacter pylori in patients with systemic sclerosis: detection with the 13C-urea breath test and eradication. Acta Derm Venereol. 1994;74:361-3.

16. Yazawa N, Fujimoto M, Kikuchi K, Kubo M, Ihn H, Sato S, et al. High seroprevalence of Helicobacter pylori infection in patients with systemic sclerosis: association with esophageal involvement. J Rheumatol. 1998; 25:650-3.

17. Magen E, Delgado JS. Helicobacter pylori and skin autoimmune diseases. World J Gastroenterol. 2014;20:1510-6.

18. Di Paolo S. Metformin ameliorates extreme insulin resistance in a patient with anti-insulin receptor antibodies: description of insulin receptor and postreceptor effects in vivo and in vitro. Acta Endocrinol (Copenh). 1992;126:117-23.
19. Hong L, Zhao Y, Han Y, Guo W, Wang J, Li X, et al. Reversal of migraine symptoms by Helicobacter pylori eradication therapy in patients with hepatitis-B-related liver cirrhosis. Helicobacter. 2007;12:306-8.

20. Dogan Z, Sarikaya M, Ergul B, Filik L. The effect of Helicobacter pylori eradication on insulin resistance and $\mathrm{HbA} 1 \mathrm{c}$ level in people with normal glucose levels: a prospective study. Biomed Pap Med Fac Univ Palacky Olomouc Czech Repub. 2014;159(2):242-5.

\section{Submit your next manuscript to BioMed Central and we will help you at every step:}

- We accept pre-submission inquiries

- Our selector tool helps you to find the most relevant journal

- We provide round the clock customer support

- Convenient online submission

- Thorough peer review

- Inclusion in PubMed and all major indexing services

- Maximum visibility for your research

Submit your manuscript at www.biomedcentral.com/submit 